\title{
Species composition of Sididae (Branchiopoda: Cladocera) in Vientiane Province and Vientiane City, Laos
}

\author{
S. Siboualipha1, N.M. Korovchinsky², L. Sanoamuang ${ }^{1,3^{*}}$ \\ ${ }^{1}$ Applied Taxonomic Research Center, Department of Biology, Faculty of Science, KhonKaen \\ University, KhonKaen 40002, Thailand. E-mail: sompong.siboua55@gmail.com \\ ${ }^{2}$ A.N. Severtsov Institute of Ecology and Evolution, Leninsky prospect 33, Moscow 119071, Russian \\ Federation.E-mail: nmkor@yandex.ru \\ ${ }^{3}$ International College, KhonKaen University, KhonKaen 40002, Thailand. E-mail: \\ la_orsri@kku.ac.th \\ *Corresponding author: la_orsri@kku.ac.th
}

ABSTRACT: The species composition of the Sididae (Branchiopoda: Cladocera) of Laos (Vientiane Province and Vientiane City) was studied, based on 52 samples from 28 localities. Five species were recorded, with the genus Diaphanosoma represented by three. Two other genera, Pseudosida and Sida, had one species each (Pseudosida szalayi Daday, 1898 and Sida cf. americana Korovchinsky, 1979). The latter taxon, probably invasive, is new to Laos and to South-East Asia. In most cases two species of Sididae co-occurred but in eight localities combinations of three and four species were seen.

How to cite this article: Siboualipha S., Korovchinsky N.M., Sanoamuang L. 2020. Species composition of Sididae (Branchiopoda: Cladocera) in Vientiane Province and Vientiane City, Laos // Invert. Zool. Vol.17. No.2. P.162-175. doi: 10.15298/invertzool.17.2.06

KEY WORDS: Cladocera, Sididae, species composition, Laos, South-East Asia.

\section{Видовой состав семейства Sididae (Branchiopoda: Cladocera) в провинции Вьентьян и городе Вьентьян, Лаос}

\footnotetext{
С. Сибоуалифа ${ }^{1}$, Н.М. Коровчинский ${ }^{2}$, Л. Саноамуанг ${ }^{1,3^{*}}$

${ }^{I}$ Applied Taxonomic Research Center, Department of Biology, Faculty of Science, KhonKaen University, KhonKaen 40002, Thailand. E-mail: sompong.siboua55@gmail.com

${ }^{2}$ Институт проблем экологии и эволюиии им. А.Н. Северцова РАН, Ленинский проспект 33, 119071 Москва, Российская Федераиия. E-mail: nmkor@yandex.ru

${ }^{3}$ International College, KhonKaen University, KhonKaen 40002, Thailand. E-mail: la_orsri@kku.ac.th

*Āдрес для корреспонденции: la_orsri@kku.ac.th
}

РЕЗЮМЕ: Впервые, на основании обработки 52 проб, собранных в 28 местонахождениях, подробно исследован видовой состав представителей семейства Sididae центрального района Лаоса (провинция Вьентьян и город Вьентьян). В целом обнаружено пять видов семейства, род Diaphanosoma был представлен тремя видами. Два других рода, Pseudosida и Sida, были представлены одним видом каждый (P. szalayi Daday, 1898 и S. cf. americana Korovchinsky, 1979, соответственно). Последний таксон, вероятно инвазивный, отмечен как новый для лаосской фауны, а также 
и для Юго-Восточной Азии в целом. В большинстве случаев было отмечено сосуществование двух видов Sididae, но в восьми местонахождениях найдено вместе по три или четыре вида.

Как цитировать эту статью: Siboualipha S., Korovchinsky N.M., Sanoamuang L. 2020. Species composition of Sididae (Branchiopoda: Cladocera) in Vientiane Province and Vientiane City, Laos // Invert. Zool. Vol.17. No.2. P.162-175. doi: 10.15298/invertzool. 17.2.06

КЛЮЧЕВЫЕ СЛОВА: Cladocera, Sididae, видовой состав, Лаос, Юго-Восточная Азия.

\section{Introduction}

Cladocera are freshwater microcrustaceans, monophyletic (Martin, Cash-Clark, 1995; Richter et al., 2007), and an important component of aquatic ecosystems. They predominantly inhabit continental water bodies of different types all over the world and are especially abundant in stagnant waters (Dumont, Negrea, 2002; Forró et al., 2008). They represent four orders of the Branchiopoda, one of which, the Ctenopoda, is dealt with here.

One family, the Sididae is widely distributed and is most diverse and abundant in tropical, subtropical, and southern temperate latitudes. It is present though less dominant in all climatic zones, and on all continents save Antarctica. Its representatives (e.g., Sida spp., Diaphanosoma spp.) often dominate the pelagic and littoral zooplankton communities. Analysis of novel information reveals that the world fauna of the family Sididae currently includes 64 valid taxa of at the species-group level (Korovchinsky, 2018).

Laos is one of the least explored countries of South-East Asia in respect of its Cladocera fauna (Korovchinsky, 2013). Heckman (1974) published the first faunistic list, that included seven species, of which only one, Latonopsis australis Sars, 1888, was of a Sididae family. In the 2000s, two faunistic reports were made but remained unpublished (see Kotov et al., 2013). The next species record concerned the species Diaphanosoma senegal isanensis Korovchinsky et Sanoamuang, 2008, found in the southern Champasak Province of Laos (Korovchinsky, Sanoamuang, 2013).The most comprehensive publication on Laotian Cladocera (Kotov et al., 2013), prepared recently by the international research team cited 70 species, five of which were Sididae.

The present investigation focuses exclusively on the Sididae, which are sometimes especially numerous and play a significant role in both pelagic and littoral tropical freshwater communities (Korovchinsky, Sanoamuang, 2008, 2013). They were poorly surveyed in previous studies. Our aim here is to revise the Sididae of the central part of Laos (Vientiane Province and Vientiane City) based on an abundant material collected in water bodies of various types.

\section{Study area, material and methods}

Laos is a tropical country situated in SouthEast Asia that borders with China, Cambodia, Thailand, Myanmar, and Vietnam (Fig.1). Samples were collected in the central part of the country (Vientiane Province and Vientiane City) (Fig. 2) where plenty of various water bodies are located. Each locality was abbreviated either VTP (Vientiane Province) or VTC (Vientiane City). Samples were collected qualitatively from February to April 2013 and from November to December 2014 using $60 \mu \mathrm{m}$ plankton net from 28 localities. In total, 52 samples have been taken in the following water bodies of different types:

Large permanent water bodies with welldeveloped vegetation

1) VTC08, lake with abundant vegetation, Nakhanthoung village, $18.16056^{\circ} \mathrm{N} ; 102$. $46187^{\circ} \mathrm{E}$.

2) VTC09, large swamp, Nong Ngom, $18.13602^{\circ} \mathrm{N} ; 102.49417^{\circ} \mathrm{E}$. 


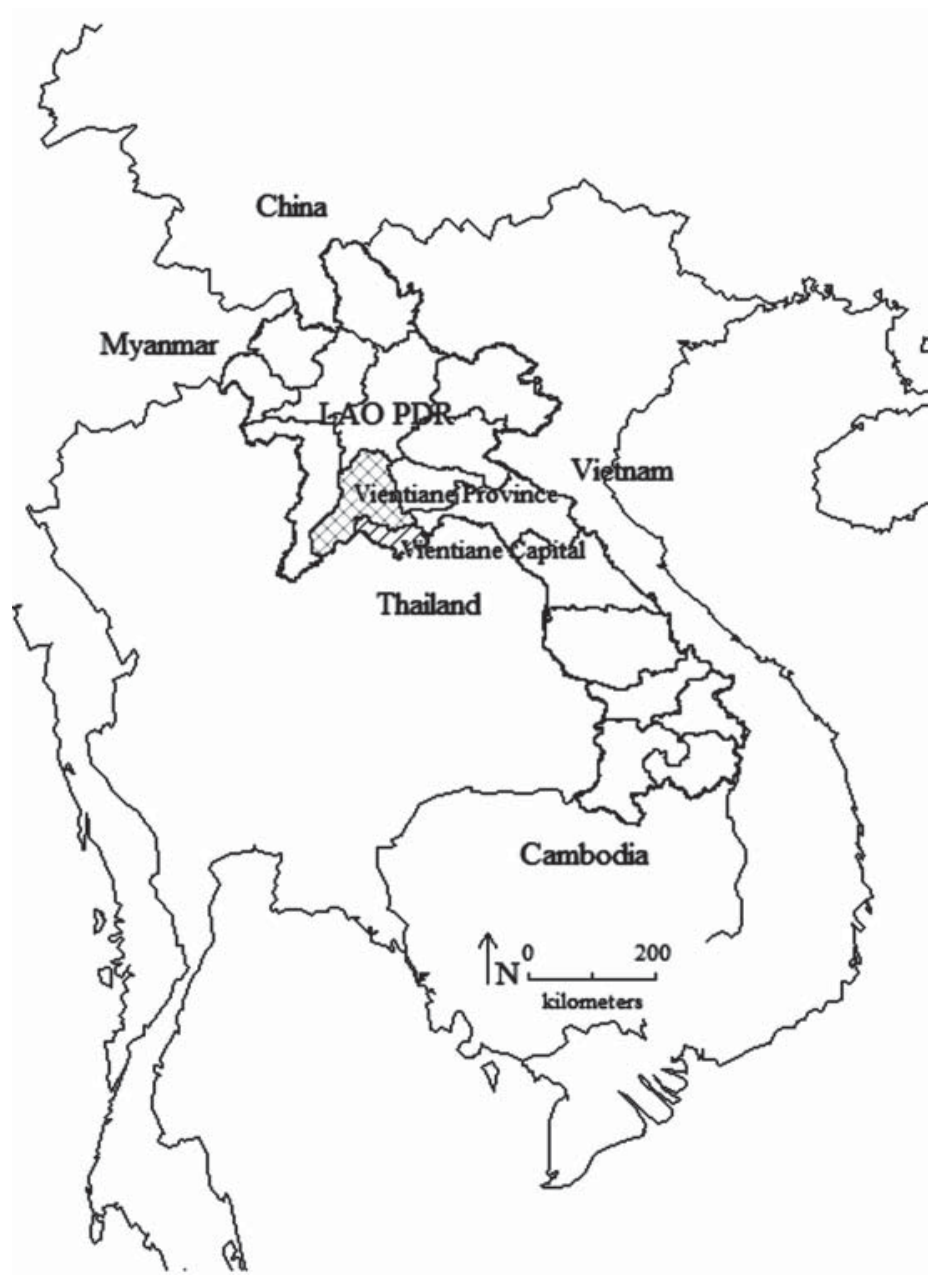

Fig. 1. A map of Laos and neighboring countries of South-East Asia (the area of Vientiane Province and Vientiane City is highlighted).

Рис. 1. Карта Лаоса и соседних стран Юго-Восточной Азии (район провинции Вьентьян и города Вьентьян выделен).

3) VTC15, large lake, Nong Xeum, 18. $07085^{\circ} \mathrm{N} ; 102.39270^{\circ} \mathrm{E}$.

4) VTC19, large irrigation reservoir, Nam Xuang, $18.14777^{\circ} \mathrm{N} ; 102.27825^{\circ} \mathrm{E}$.

5) VTP50, large swamp, Bankeun village, $18.21894^{\circ} \mathrm{N} ; 102.37953^{\circ} \mathrm{E}$.

6) VTC58, irrigation reservoir, Num Houm, $18.10414^{\circ} \mathrm{N} ; 102.27945^{\circ} \mathrm{E}$.

Small semi-permanent water bodies without abundant vegetation

7) VTC10, roadside channel, Nakhanthoung village $2,18.15053^{\circ} \mathrm{N} ; 102.48021^{\circ} \mathrm{E}$.
8) VTC11, roadside channel, Nakhanthoung village $3,18.15710^{\circ} \mathrm{N} ; 102.46670^{\circ} \mathrm{E}$.

9) VTP12, roadside channel, Haiyon village, $18.17266^{\circ} \mathrm{N} ; 102.40641^{\circ} \mathrm{E}$.

10) VTC16, roadside channel, Phonehaikham village, $18.14338^{\circ} \mathrm{N} ; 102.41477^{\circ} \mathrm{E}$.

11) VTC18, small irrigation dam, Phonexay village, $18.14924^{\circ} \mathrm{N} ; 102.27979^{\circ} \mathrm{E}$.

12) VTP43, roadside channel, Phonehong village, $18.27715^{\circ} \mathrm{N} ; 102.24557^{\circ} \mathrm{E}$.

13) VTP44, roadside channel, way to $\mathrm{Hin} \mathrm{Pa}$ Pha waterfall, $18.17006^{\circ} \mathrm{N} ; 102.44260^{\circ} \mathrm{E}$. 


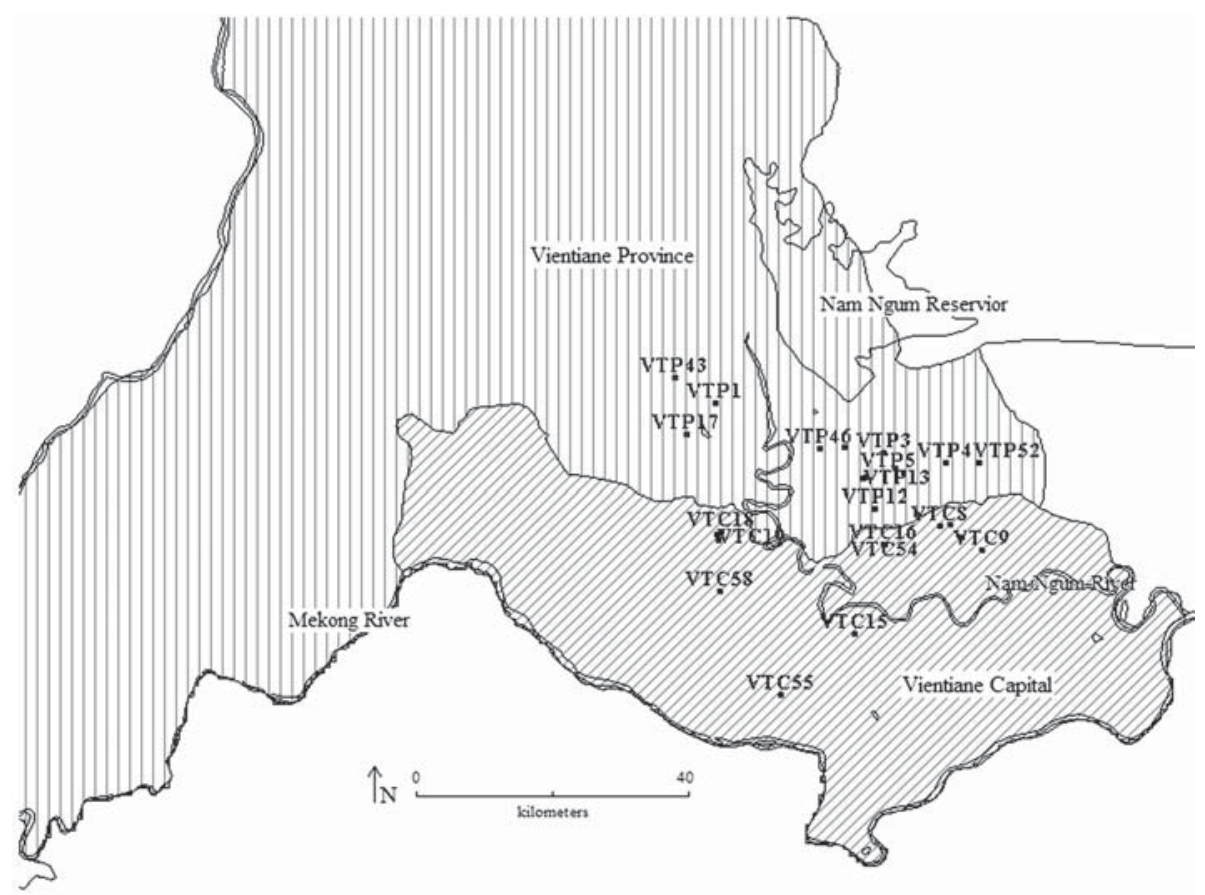

Fig. 2. Map of sampling sites in Vientiane province (VTP) and Vientiane City (VTC).

Рис. 2. Карта места сбора материала в провинции Вьентьян (VTP) и в городе Вьентьян (VTC).

14) VTP46, roadside channel, Phonsavath village, $18.21791^{\circ} \mathrm{N} ; 102.36359^{\circ} \mathrm{E}$.

15) VTP49, roadside channel, Park hang village, $18.20009^{\circ} \mathrm{N} ; 102.39793^{\circ} \mathrm{E}$.

16) VTC54, roadside channel,Thong Mung village, $18.14310^{\circ} \mathrm{N} ; 102.41485^{\circ} \mathrm{E}$.

17) VTC55, roadside channel, Sikerud village, $18.02112^{\circ} \mathrm{N} ; 102.32847^{\circ} \mathrm{E}$.

Temporary pond and pools

18) VTP14, large temporary pool with abundant vegetation, Koudsambad village, 18. $15710^{\circ} \mathrm{N} ; 102.46670^{\circ} \mathrm{E}$.

19) VTP51, pond, road to Mum Mung Dam, $18.20431^{\circ} \mathrm{N} ; 102.41981^{\circ} \mathrm{E}$.

20) VTC20, rock pool near a small artificial Nam Xuang water fall, $18.14501^{\circ} \mathrm{N} ; 102$. $28240^{\circ} \mathrm{E}$.

\section{Forest streams and rivers}

21) VTP01, small slowly flowing river without abundant vegetation (Namcheng River), $18.25667^{\circ} \mathrm{N} ; 102.27699^{\circ} \mathrm{E}$.

22) VTP03, small slowly flowing forest stream, $18.21624^{\circ} \mathrm{N} ; 102.41466^{\circ} \mathrm{E}$.
23) VTP04, large slowly flowing river with abundant vegetation (Nam Mang 1), 18.20691 ${ }^{\circ}$ $\mathrm{N} ; 102.46457^{\circ} \mathrm{E}$.

24) VTP05, large slowly flowing river with abundant vegetation (Nam Mang 2), 18.20439 $\mathrm{N} ; 102.41980^{\circ} \mathrm{E}$.

25) VTP06, river under the bridge on the road to Nam Mang Dam 3, $18.20439^{\circ} \mathrm{N}$; $102.41980^{\circ} \mathrm{E}$.

26) VTP13, small river with abundant vegetation, Napheng bridge, $18.19556^{\circ} \mathrm{N}$; $102.40060^{\circ} \mathrm{E}$.

27) VTP17, small Nam Phanai river with poor vegetation, $18.22937^{\circ} \mathrm{N} ; 102.25486^{\circ} \mathrm{E}$.

28) VTP52, small forest stream, Vang Heua village, $18.21100^{\circ} \mathrm{N} ; 102.48908^{\circ} \mathrm{E}$.

Environmental variables (water temperature, $\mathrm{pH}$, conductivity, TDS) were measured in parallel. Samples were taken three times at each locality, including littoral and pelagic areas, and preserved by formaldehyde (4\%). The taxonomic analysis was conducted at the Applied Taxonomic Research Center (Khon Kaen 
Table 1. Species of Sididae found in Laos and their localities. Таблица 1. Виды Sididae, найденные в Лаосе, и их местонахождения.

\begin{tabular}{|c|c|}
\hline Taxa & Localities \\
\hline $\begin{array}{l}\text { Diaphanosoma dubium } \\
\text { Manuilova, } 1964\end{array}$ & $\begin{array}{l}\text { VTP01, VTP14, VTC15, VTP17, VTC20, VTP49, } \\
\text { VTP51, VTC54 }\end{array}$ \\
\hline $\begin{array}{l}\text { Diaphanosoma excisum Sars, } \\
1885\end{array}$ & $\begin{array}{l}\text { VTP01, VTP03, VTP05, VTP06, VTC08, VTC10, } \\
\text { VTC11, VTP12, VTP14, VTC15, VTC16, VTP17, } \\
\text { VTC18, VTC20, VTP43, VTP44, VTP46, VTP51, } \\
\text { VTP52, VTC54, VTC58 }\end{array}$ \\
\hline $\begin{array}{l}\text { Diaphanosoma sarsi Richard, } \\
1894\end{array}$ & $\begin{array}{l}\text { VTP01, VTP03, VTP04, VTC09, VTC10, VTC11, } \\
\text { VTP12, VTP13, VTC15, VTC16, VTP17, VTC19, } \\
\text { VTC20, VTP43, VTP46, VTP50, VTC55 }\end{array}$ \\
\hline Pseudosida szalayi (Daday, 1898) & VTC08, VTC16, VTP50, VTC55 \\
\hline $\begin{array}{l}\text { Sida } \text { cf. americana } \\
\text { Korovchinsky, 1979* }\end{array}$ & $\begin{array}{l}\text { VTP01, VTP06, VTC08, VTP12, VTP13, VTP14, } \\
\text { VTC16, VTP17, VTP44 }\end{array}$ \\
\hline
\end{tabular}

Remarks: *new species to Laos; VTP — Vientiane province; VTC — Vientiane City.

University, Thailand). Figures were prepared using an Olympus CHD compound microscope with camera lucida. One species, Sida cf. americana, was studied in more detail with body parts measurements according to Korovchinsky (2004).

\section{Results}

Species richness and frequency distribution. In total, five species of the family Sididae have been found (Table 1); members of the genus Diaphanosma Fischer, 1850 were most numerous being represented by three species.
Other two genera, Pseudosida Herrick, 1884 and Sida Straus, 1820 were represented by one species each: P. szalayi Daday, 1898 and S. cf. americana Korovchinsky, 1979. The latter was a new species to Laos fauna.

The frequency distributions of particular species is shown in Fig. 3. The most frequently encountered species always was $D$. excisum Sars, 1885 , found in $75 \%$ of all localities. It was followed by $D$. sarsi Richard, 1894 (60.7\%), S. cf. americana $(32.1 \%)$, and D. dubium Manuilova, 1964 (28.6\%). P.szalayi was rarest being found in $14.3 \%$ of localities.

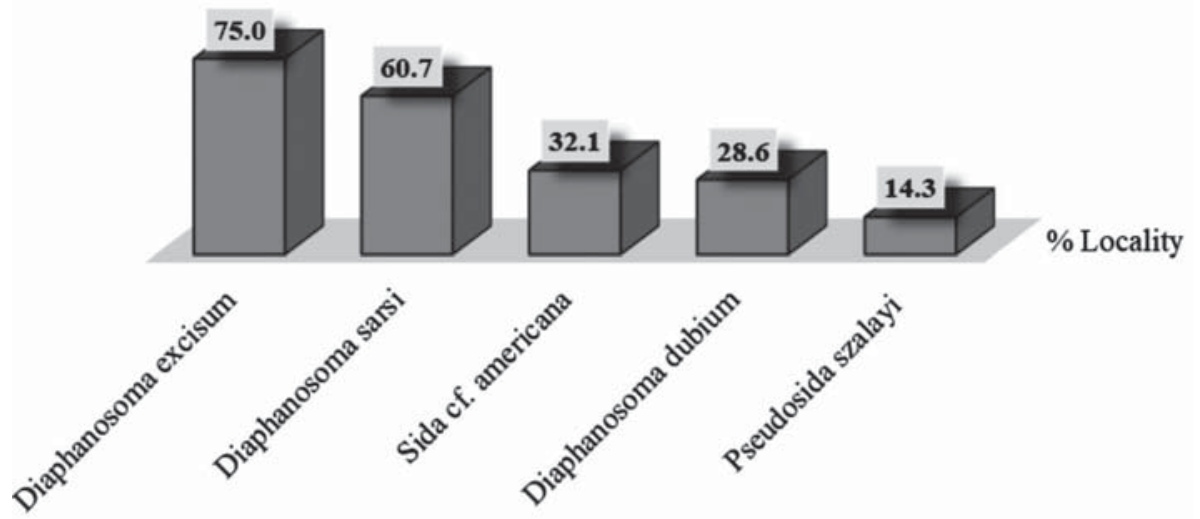

Fig. 3. The frequency distribution of Sididae species in studied area.

Рис.3. Частота встречаемости видов Sididae в исследованном районе. 
Table 2. Measurement of body parts' proportions of adult females of Sida cf. americana (n=20) (in each column from top to down: Range, Mean, and SD).

Таблица 2. Измерения пропорций частей тела взрослых самок Sida cf. americana (n=20) (в каждой колонке сверху вниз: интервал значений, среднее арифметическое, среднее квадратичное

отклонение).

\begin{tabular}{|c|c|c|c|c|c|c|}
\hline $\begin{array}{c}\text { HL: BL } \\
(\%)\end{array}$ & $\begin{array}{c}\text { HH: BL } \\
(\%)\end{array}$ & $\begin{array}{c}\text { DE: BL } \\
(\%)\end{array}$ & $\begin{array}{c}\text { LSA: BL } \\
(\%)\end{array}$ & $\begin{array}{c}\text { BaL: LSA } \\
(\%)\end{array}$ & $\begin{array}{c}\text { LUAB: } \\
\text { LSA }(\%)\end{array}$ & $\begin{array}{c}\text { LLAB:LSA } \\
(\%)\end{array}$ \\
\hline $27.8-42.8$ & $21.6-39.7$ & $7.1-10.3$ & $44.5-64.3$ & $43.9-58.3$ & $47.5-54.9$ & $47.5-55.0$ \\
\hline 37.5 & 29.2 & 8.6 & 57.6 & 53.0 & 51.1 & 51.1 \\
\hline 5.5 & 6.0 & 1.2 & 6.5 & 3.8 & 2.5 & 2.5 \\
\hline
\end{tabular}

BL — body length, HL — head length, HH — head height, DE — diameter of eye, LSA — length of swimming antennae, BaL - length of antennal basipodite, LUAB - length of upper antennal branch, LLAB - length of lower antennal branch.

Table 3. Type of water bodies and environmental variables at which Sididae species were found.

Таблица 3. Типы водоемов и параметры среды, при которых были найдены виды Sididae.

\begin{tabular}{|l|c|c|c|c|c|}
\hline \multicolumn{1}{|c|}{ Species } & Types of water body & $\mathrm{pH}$ & $\begin{array}{c}\text { Conductivity } \\
(\mu \mathrm{S})\end{array}$ & $\begin{array}{c}\text { TDS } \\
(\mathrm{ppm})\end{array}$ & $\begin{array}{c}\text { Temperature } \\
\left({ }^{\circ} \mathrm{C}\right)\end{array}$ \\
\hline $\begin{array}{l}\text { Diaphanosoma } \\
\text { dubium }\end{array}$ & $\begin{array}{c}\text { rivers, lake, roadside } \\
\text { channels, swamp, } \\
\text { pond, rock pool, } \\
\text { temporary pool }\end{array}$ & $\begin{array}{c}5.8- \\
8.7\end{array}$ & $4-201$ & $2-74$ & $21.3-34.9$ \\
\hline D. excisum & $\begin{array}{c}\text { lakes, rivers, streams, } \\
\text { reservoirs, roadside } \\
\text { channels, pond, } \\
\text { temporary pool, rock } \\
\text { pool }\end{array}$ & $\begin{array}{c}6.1- \\
8.7\end{array}$ & $34-201$ & $16-71$ & $27.8-34.9$ \\
\hline D. sarsi & $\begin{array}{c}\text { rivers, stream, } \\
\text { swamps, roadside } \\
\text { channels, pond, } \\
\text { reservoir, rock pool }\end{array}$ & $\begin{array}{c}5.6- \\
7.2\end{array}$ & $6-489$ & $2-249$ & $21.3-43.1$ \\
\hline $\begin{array}{c}\text { swamp, heavily } \\
\text { vegetated lake, } \\
\text { szalayi }\end{array}$ & $\begin{array}{c}6.4- \\
\text { roadside channels }\end{array}$ & 6.9 & $14-498$ & $7-249$ & $28.6-31.6$ \\
\hline $\begin{array}{l}\text { Sida } \text { cf. } \\
\text { americana }\end{array}$ & $\begin{array}{c}\text { rivers, lake, roadside } \\
\text { channels, temporary } \\
\text { pool }\end{array}$ & $\begin{array}{c}5.8- \\
7.2\end{array}$ & $10-125$ & $5-57$ & $24.4-33.7$ \\
\hline
\end{tabular}

Notes on particular species. Data on water bodies and environmental variables for each species are shown in Table 3.

1) Diaphanosoma dubium (Figs 4, 5). This species is characterized by a large, dorsally protruding head with eye shifted ventrally, thin, hardly visible seta on distal basipodital outer end of swimming antennae, postero-ventral valve margin with a row of usually 12-29 slightly curved denticles and a number of setules between them, absence of inner dorsal thorn(s) near posterior valve margin, and postabdomen usually prominent dorsally (see Korovchinsky (2018) for more details). It was found in a lake, rivers, swamp, roadside channels, pond, rock pool and ones especially abundantly in a temporary pool. In rainy season, the latter one turns into a large swamp surrounded by rice fields. 


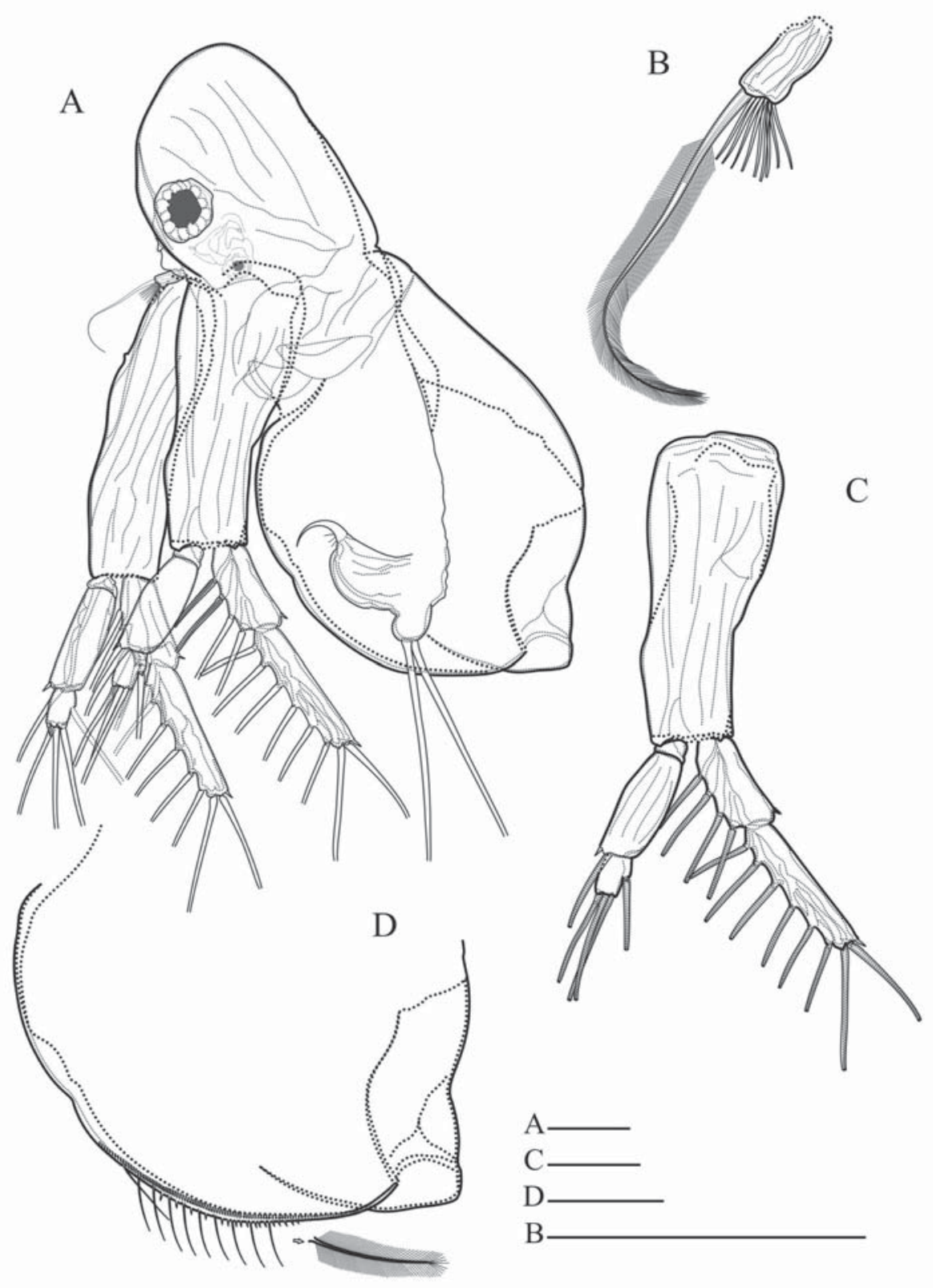

Fig. 4. Diaphanosoma dubium Manuilova, 1964,, (VTP14): A — general lateral view; B — antennula; C swimming antenna, lateral view; D - shell valve, outer side. Scale bars: $0.05 \mathrm{~mm}$.

Рис. 4. Diaphanosoma dubium Manuilova, 1964, + (VTP14): А - общий вид сбоку; В - антеннула; C плавательная антенна, вид сбоку; D - створка раковинки с внешней стороны. Масштаб: 0,05 мм.

2) Diaphanosoma excisum. This species is characterized by a relatively large rectangular head with a fairly large dorsal part and eye situated closer to its anterior-ventral side, pres- ence of a sharp spine on distal basipodital outer end of swimming antennae, rather wide flap gradually tapering distally without depression, 4-18 large, sharp denticles without setules be- 

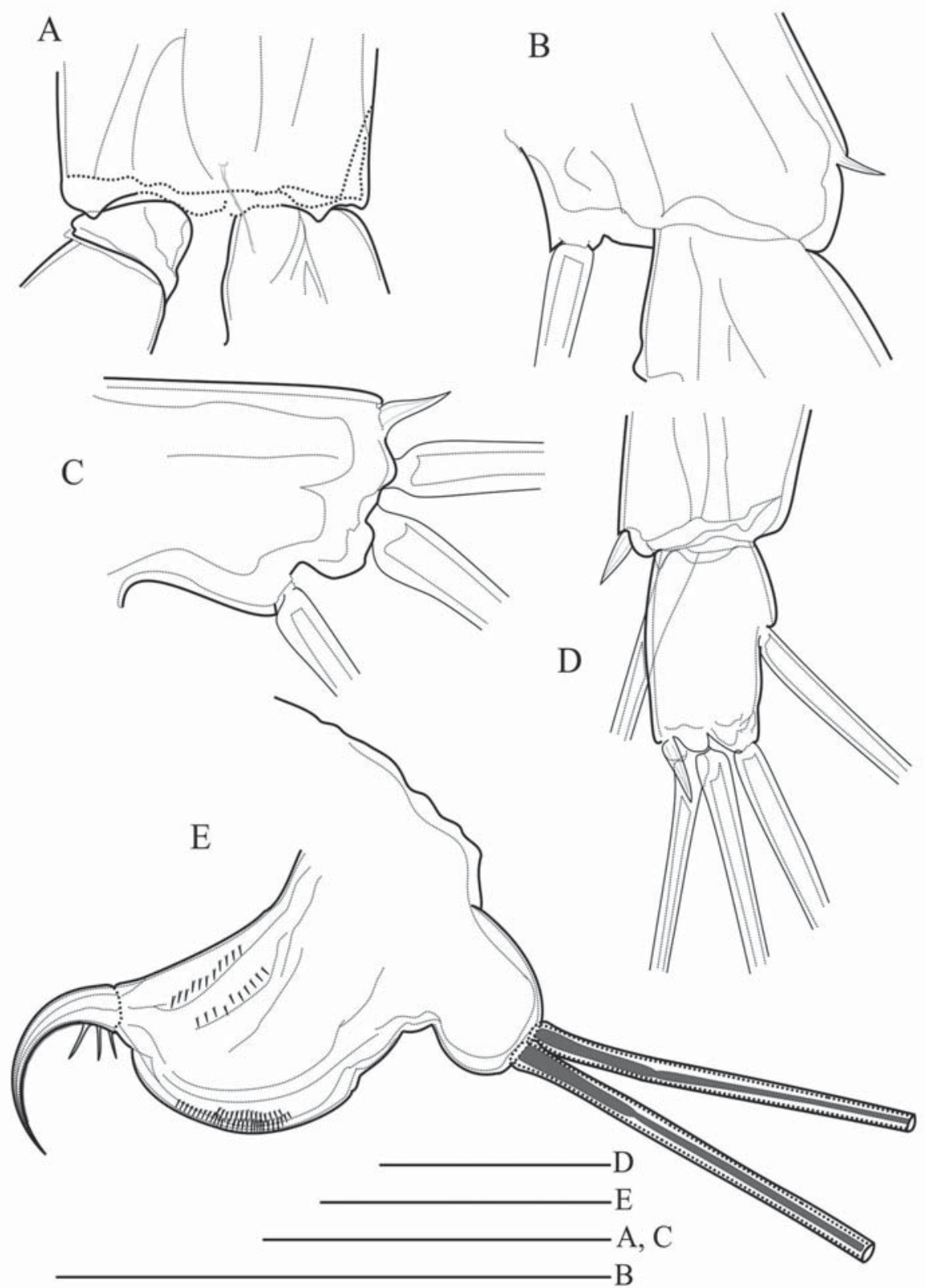

Fig. 5. Diaphanosoma dubium Manuilova, 1964, $q$ (VTP14): A — distal part of basipodite of swimming antenna, outer view; B - distal part of first segment of upper antennal branch; C - distal part of second segment of upper antennal branch; D - distal part of lower 3-segmented antennal branch; E postabdomen, lateral view. Scale bars: $0.05 \mathrm{~mm}$.

Рис. 5. Diaphanosoma dubium Manuilova, 1964, q (VTP14): А - дистальная часть плавательной антенны, вид сбоку; В — дистальная часть первого членика верхней ветви антенны; С — дистальная часть второго членика верхней ветви антенны; D - дистальная часть нижней ветви антенны; Е постабдомен, вид сбоку. Масштаб: 0,05 мм. 


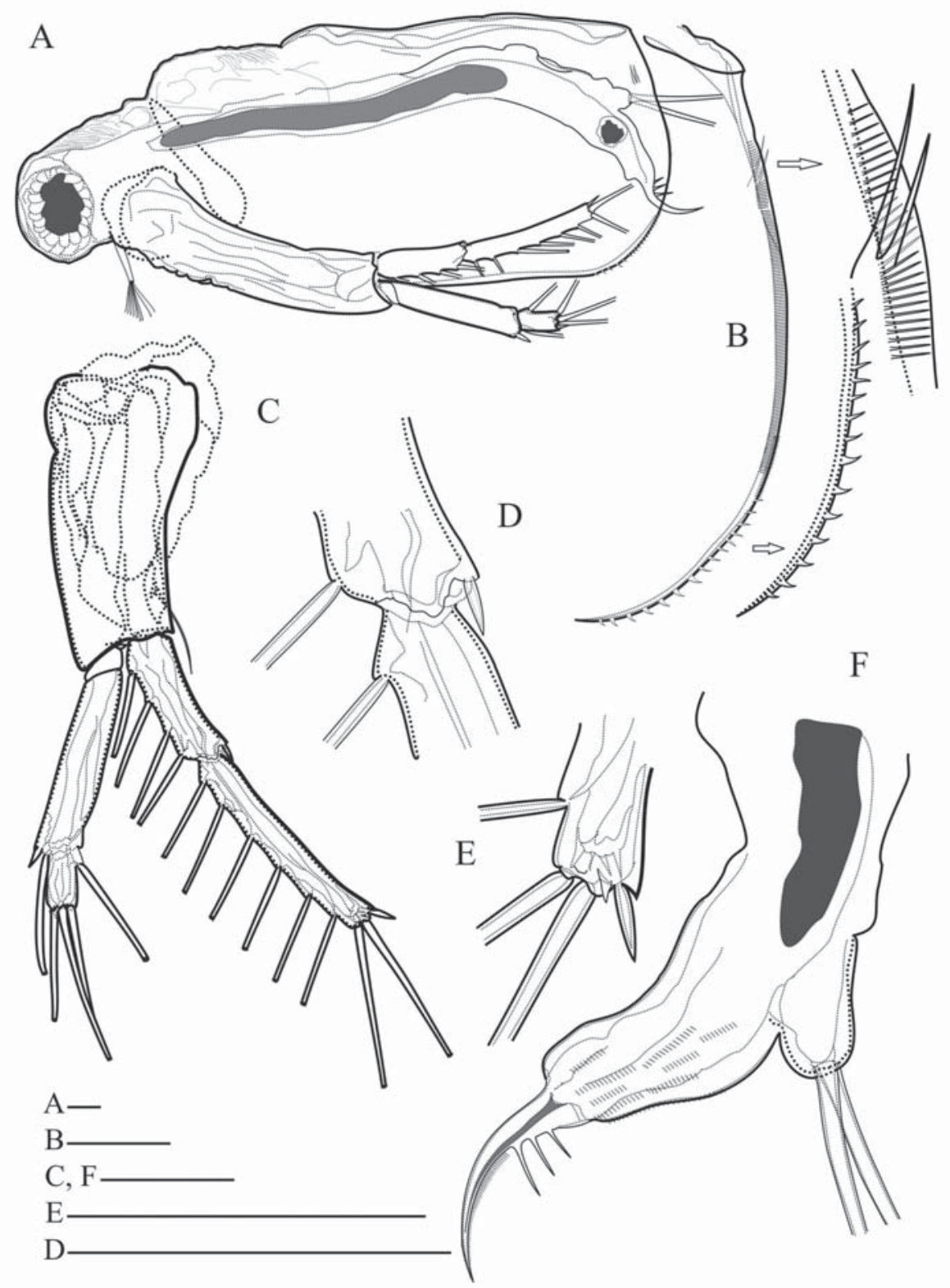

Fig. 6. Diaphanosoma sarsi Richard, 1894, 9 (VTP09): A — general lateral view; B — postero-ventral valve margin and denticles near posterior valve margin; $\mathrm{C}$ - swimming antenna, lateral view; $\mathrm{D}$ - distal part of first segment of upper antennal branch; E - apical end of upper antennal branch; F - postabdomen, lateral view. Scale bars: $0.025 \mathrm{~mm}$.

Pис. 6. Diaphanosoma sarsi Richard, 1894, 9 (VTP09): А - общий вид сбоку; В - задне-нижний край створки и шипики у заднего края створки; C - плавательная антенна, вид сбоку; D - дистальная часть первого членика верхней ветви антенны; $\mathrm{E}$ - апикальный конец верхней ветви антенны; $\mathrm{F}$ постабдомен, вид сбоку. Масштаб: 0,025 мм. 


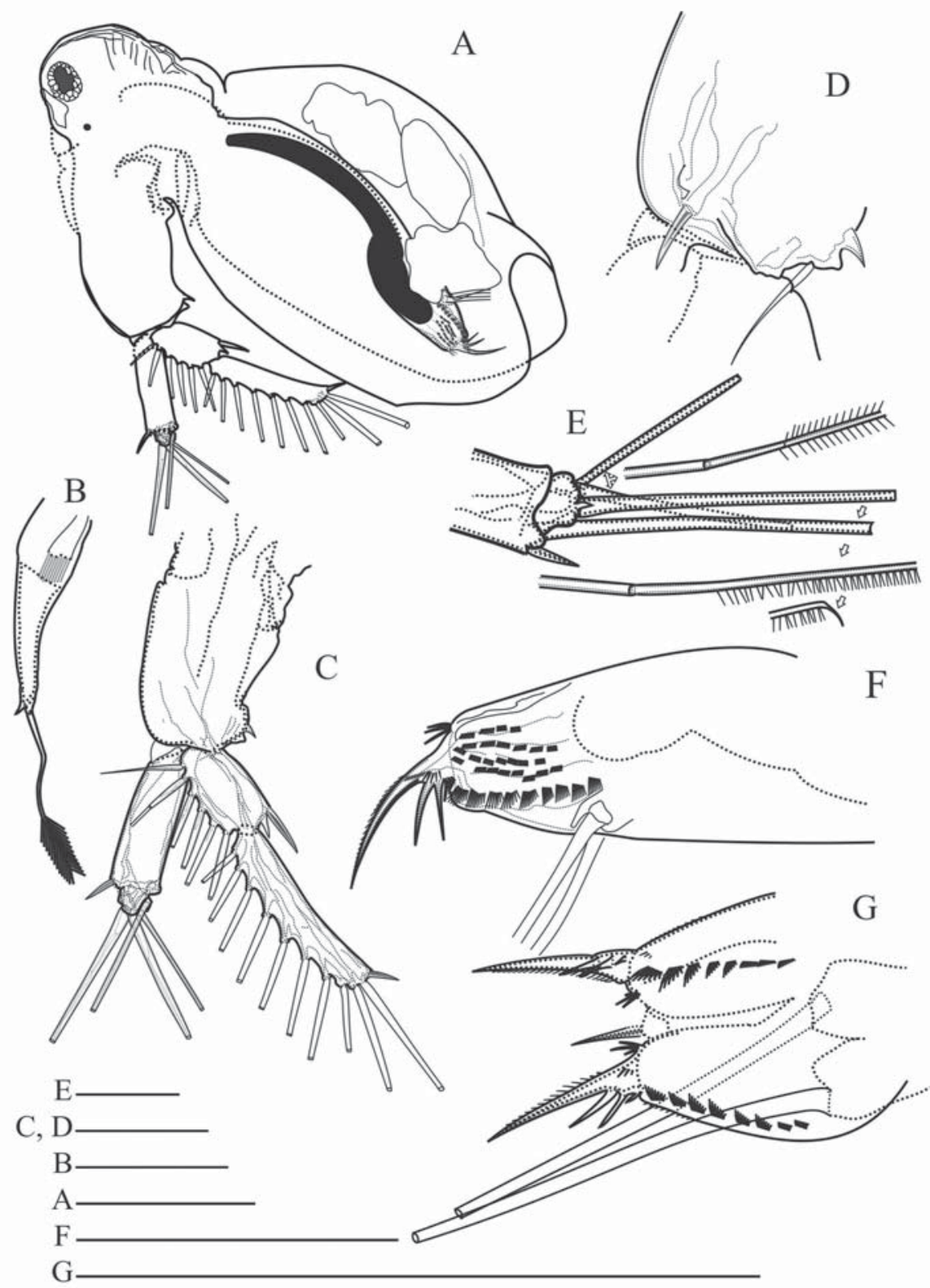

Fig. 7. Pseudosida szalayi (Daday, 1898), 9 (VTP55) (A, B, C, D, E) and VTP54 (F, G): A - general lateral view; B - antennula; C - swimming antenna; D — distal outer end of antennal basipodite; E — distal part of lower antennal branch and armament of distal setae; F - postabdomen, lateral view; $\mathrm{G}$ - distal end of postabdomen, dorsal view. Scale bars: $0.05 \mathrm{~mm}$.

Рис. 7. Pseudosida szalayi (Daday, 1898), ๆ (VTP55) (A, В, C, D, E) и VTP54 (F, G): A - общий вид сбоку; В — антеннула; C — плавательная антенна; D — дистальный конец базиподита плавательной антенны с внешней стороны; Е - дистальный членик нижней ветви плавательной антенны и вооружение дистальных щетинок; $\mathrm{F}$ - постабдомен, вид сбоку; $\mathrm{G}$ - дистальный конец постабдомена, вид с дорсальной стороны. Масштаб: 0,05 мм. 
tween them on postero-ventral valve margins, and two inner dorsal thorns on posterior valve margins (see Korovchinsky (2018) for more details). It was distributed especially broadly inhabiting almost all types of studied water bodies.

3) Diaphanosoma sarsi (Fig. 6). This species is characterized by a round-rectangular head with large eye, ventral flap-shaped inflexion of valves with a rather narrow cut near its junction with the postero-ventral margin, so that the roundish distal part of the ventral valve inflexion hardly projects backwards, and postero-ventral valve margins with a row of usually 16-28 small denticles diminishing dorsally (see Korovchinsky (2018) for more details). The representatives of the species have been found in various types of water bodies such as a large lake, large swamp, rivers, forest stream, roadside channels, reservoir, pond and a rock pool.

4) Pseudosida szalayi (Fig. 7). It is characterized by a rounded head with eye situated frontally. Swimming antennae long with massive basipodite, their upper branch bears numerous setae whereas lower branch always bears four setae two distal of which are especially long, massive, and having hooked ends. Postabdomen with prominent terminal outgrowth between base of claws, its anal teeth are grouped in 10-12 clusters, postabdominal claws with three basal spines, the proximal of which is much smaller than others (see Korovchinsky (2018) for more details). This species was found in a large swamp, heavily vegetated lake, and in roadside channels.

5) Sida cf. americana (Fig. 8). The body measurements of 20 adult parthenogenetic females are shown in Table 2. Head large, oblongoval with anchoring dorsal organ and rostrum (Fig. 8A, B). Rostrum is relatively long and straight with tip directed backwards. Eye large situated close to ventral side of head. Both branches of swimming antennae (Fig. 8D) consist of three segments. Shell rectangular with small denticles of different size along ventral valve margins (Fig. 8G). Postabdomen with long, slightly curved row of anal teeth gradually decreasing in size proximally. Terminal claws with four basal spines the proximal of which is rather large (Fig. 8H, I). Proximal part of postabdomen's dorsum is strongly prominent. The species was found in rivers, lake, roadside channels, and in a temporary pool.

The features of the Laotian specimens are largely consistent with the diagnosis of the species but proximal spine of their postabdominal claws is unusually large, amounting about twothirds of the length of the neighboring spine. For this reason, the taxonomic status of these specimens requires further clarification.

\section{The pairwise co-occurrence of Sididae}

Monospecific occurrences of Sididae species were observed in few localities (8), most of them (7) were occupied by $D$. excisum and $D$. sarsi and one by D. dubium (Table 4). It is clear from the table that the most common species $(D$. excisum, D.dubium, D. sarsi, S. cf. americana) especially often co-occurred. Comparatively rare species (S. cf. americana, P. szalayi) have never been found alone. All this probably suggests mostly random character of distribution of such common eurytopic species.

In most cases (12) two species of Sididae cooccurred but in eight localities combinations of three and four species were seen (Table 5). Again, the most common species (D. excisum, D. sarsi, S. cf. americana) were especially prominent. Among others, the Diaphanosoma species, close in their space partitioning and ecology, formed three-species assemblages in four localities.

\section{Discussion}

In a comprehensive publication on Laotian Cladocera (Kotov et al. 2013), five Sididae have been recorded: Diaphanosoma dubium, D. excisum, D. sarsi, Latonopsis australis s.1., and Pseudosida szalayi. Here, we encountered the same species except $L$. australis s.l. $S$. cf. americana represents new genus and species for the country and even for all South-East Asia in general. In larger scale, this is the first record of the species on the Eurasian continent! Before, the identification of the representatives of 


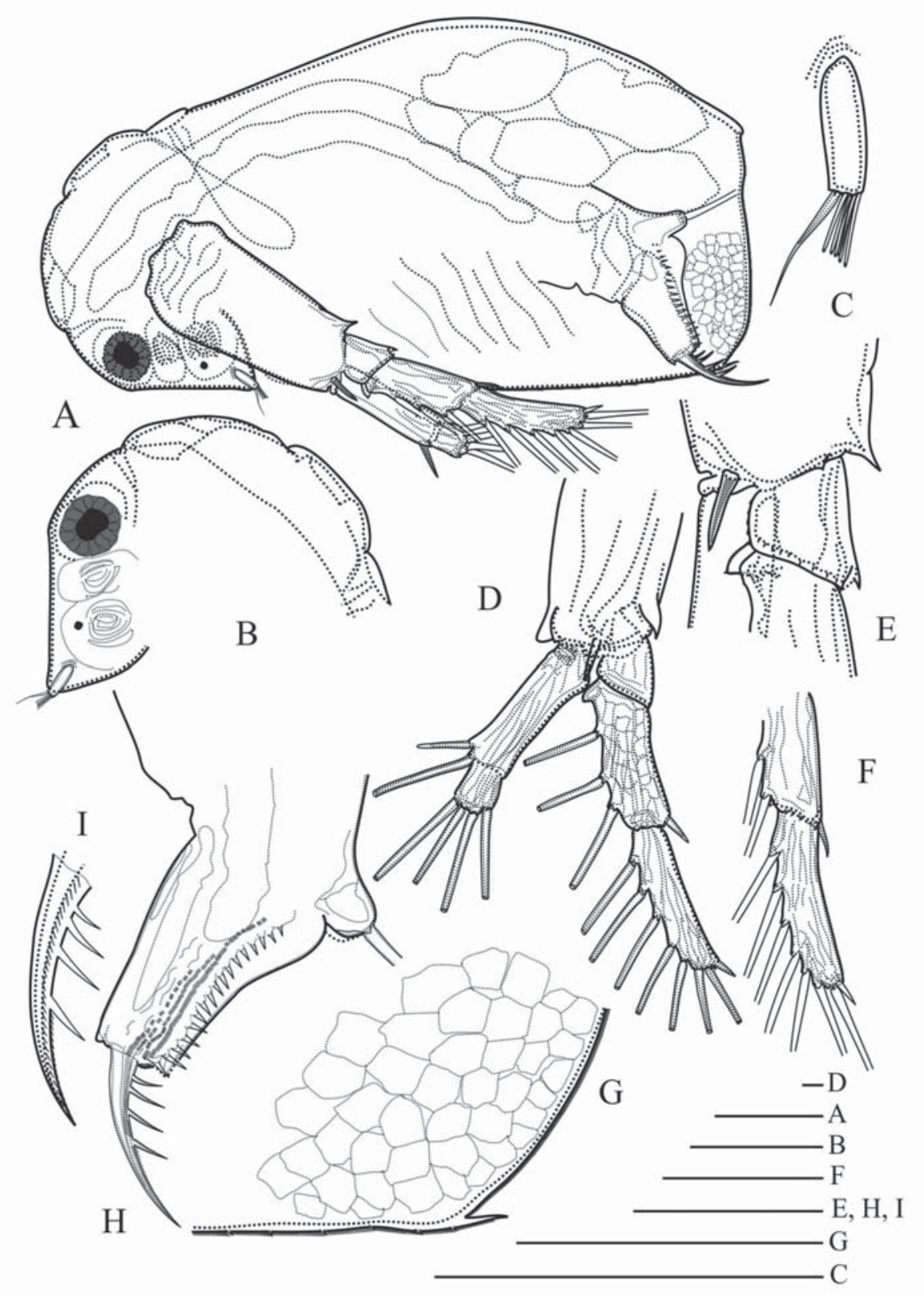

Fig. 8. Sida cf. americana Korovchinsky, 1979, ( (VTP13): A — general lateral view; B — head, lateral view; C - antennula; D - swimming antenna; E — distal part of antennal basipodite and proximal part of upper branch, outer side; F - second segment of upper antennal branch; $\mathrm{G}$ - postero-ventral portion of shell valve; $\mathrm{H}$ - postabdomen, lateral view; I - postabdominal claw. Scale bars: $0.05 \mathrm{~mm}$.

Pис. 8. Sida cf. americana Korovchinsky, 1979, q (VTP13): А - общий вид сбоку; В - голова с боковой стороны; C — антеннула; D — плавательная антенна; E — дистальная часть базиподита антенны и проксимальная часть верхней ветви с внешней стороны; $\mathrm{F}$ - второй членик верхней ветви плавательной антенны; $\mathrm{G}$ - задне-нижняя часть створки раковинки; H - постабдомен, вид сбоку; I - коготок постабдомена. Масштаб: 0,05 мм. 
Table 4. Matrix of pairwise co-occurrence of Sididae species (cells with the number of monospecific occurrences are shaded).

Таблица 4. Матрица попарного сосуществования видов Sididae (ячейки с присутствием одного вида затушеваны).

\begin{tabular}{|l|c|c|c|c|c|}
\hline \multicolumn{1}{|c|}{ Species } & D. dubium & D. excisum & D. sarsi & P. szalayi & S. cf. americana \\
\hline D. dubium & 1 & 7 & 4 & 0 & 3 \\
\hline D. excisum & 7 & 4 & 7 & 2 & 5 \\
\hline D. sarsi & 4 & 7 & 3 & 2 & 1 \\
\hline P. szalayi & 0 & 2 & 2 & 0 & 1 \\
\hline S. cf. americana & 3 & 5 & 1 & 1 & 0 \\
\hline
\end{tabular}

Table 5. Co-occurrence of three-four species of Sididae. Таблица 5. Примеры сосуществования трех-четырех видов Sididae.

\begin{tabular}{|c|c|c|c|c|c|c|}
\hline D. excisum & D. dubium & D. sarsi & P. szalayi & $\begin{array}{c}\text { S. cf. } \\
\text { americana }\end{array}$ & $\begin{array}{c}\text { No. of } \\
\text { species }\end{array}$ & $\begin{array}{c}\text { No. of } \\
\text { localities }\end{array}$ \\
\hline $\mathrm{X}$ & & $\mathrm{X}$ & & $\mathrm{X}$ & 3 & 1 \\
\hline $\mathrm{X}$ & & & $\mathrm{X}$ & $\mathrm{X}$ & 3 & 1 \\
\hline $\mathrm{X}$ & $\mathrm{X}$ & & & $\mathrm{X}$ & 3 & 1 \\
\hline $\mathrm{X}$ & $\mathrm{X}$ & $\mathrm{X}$ & & & 3 & 2 \\
\hline $\mathrm{X}$ & $\mathrm{X}$ & $\mathrm{X}$ & & $\mathrm{X}$ & 4 & 2 \\
\hline $\mathrm{X}$ & & $\mathrm{X}$ & $\mathrm{X}$ & $\mathrm{X}$ & 4 & 1 \\
\hline
\end{tabular}

the genus in South-East Asia was mostly generalized ("Sida crystallina") (e.g., Shirota, 1966; Tanaka, Ohtaka, 2010), only later they were specified as S. ortiva Korovchinsky, 1979 (=S. crystallina ortiva Korovchinsky, 1979) (Korovchinsky, Sanoamuang, 2008; Korovchinsky, 2013). This species is widely distributed all over Eastern Asia and readily penetrates SouthEast Asia, especially along the Mekong River basin (Korovchinsky, Sanoamuang, 2008). The unexpected presences of Sida cf. americana in Laos can be provisionally evaluated as species invasion which might have occurred during the military conflicts in the country in 1960-1970s. The taxon Sida americana Korovchinsky, 1979 remains poorly understood, its representatives in Laos require verification, especially their morphological difference from typical American specimens. The lack of the native species, $S$. ortiva, in the samples remains unclear.

Other species, D. excisum, D. sarsi, P. szalayi, found in Vientiane City and in its vicinity during present investigation are common tropical species widely distributed in the tropics of Eastern Hemisphere. At the same time, D. dubi- $u m$ is a species more characteristic for subtropical-southern temperate and even more northern latitudes of Eastern Asia (Korovchinsky, 2000). $P$. szalayi, being basically tropical, can penetrate far to the north up to the Amur River basin (Korovchinsky, 2010). The lack of L. australis s.l. remains unclear because this species was listed in Laos previously (Heckman, 1974; Kotov et al., 2013) as well as in the neighboring North-East Thailand where this species was quite prominent being encountered in $27 \%$ of samples (see Korovchinsky, Sanoamuang, 2008).

Of the presently recorded Diaphanosoma species, D. excisum predictably occupies the first position by frequency occurrence $(75 \%)$ as it was the case in water communities of Thailand (see Korovchinsky, Sanoamuang, 2008, 2013). The second position in this respect occupies D. sarsi being found in $60.7 \%$ of localities whereas in Thailand it was present only in $4-10 \%$ of them.

In total, seven species of Sididae have proved to be known in Laos, $S$. cf. americana, $D$. excisum, D. sarsi, D. dubium, D. senegal, $P$. szalayi and L. australis s.1., which is half of the 
known number of species of the family in the mainland South-East Asia (see Korovchinsky, Sanoamuang, 2008, 2013; Korovchinsky, 2013). Further detailed investigations are needed to reveal true species richness of Sididae and other Cladocera families in the country.

Acknowledgements. This work was supported by the Thailand Research Fund under the TRF-CAS Program for Biodiversity grant DBG6080014, and Graduate School, KhonKaen University. We are grateful to Bankeun Teacher College, (Vientiane Province) for the logistic help and travelling in Laos. NMK worked on the State Program "Ecology and biodiversity of water communities" (0109-2018-0076AAAA-A18-118042490059-5). Authors much thank the late Professor N.N. Smirnov (Institute of Ecology and Evolution, Moscow, Russia) and Professor H.J. Dumont (Gent University, Belgium) for their comments and corrections.

\section{References}

Dumont H.J., Negrea S.V. 2002. Introduction to the class Branchiopoda. Guides to the identification of the microinvertebrates of the continental waters of the world, 19. Leyden: Backhyus Publ. 398 p.

Forró L., Korovchinsky N.M., Kotov A.A., Petrusek A. 2008. Global diversity of cladocerans (Cladocera; Crustacea) in freshwater // Hydrobiologia. Vol.595. P.177-184.

Heckman C.W. 1974. The seasonal succession of species in a rice paddy in Vientiane, Laos // Int. Revue ges. Hydrobiol. Vol.59. P.489-501.

Korovchinsky N.M. 2000. Redescription of Diaphanosoma dubium Manuilova, 1964 (Branchiopoda: Ctenopoda: Sididae), and description of a new, related species // Hydrobiologia. Vol.441. P.73-92.

Korovchinsky N.M. 2004. [Cladocera Ctenopoda of the World fauna: morphology, systematics, ecology and zoogeography]. Moscow: KMK Scientific Press. 410 p. [In Russian]
Korovchinsky N.M. 2010. A taxonomic revision of Pseudosida szalayi Daday, 1898 (Crustacea: Cladocera: Sididae) over its Asian range, with focus on the northernmost populations first recorded from the Amur River basin (Far East of Russia) // Zootaxa. Vol.2345. P.1-18.

Korovchinsky N.M. 2013. Cladocera (Crustacea: Branchiopoda) of South-East Asia: history of explorations, taxon richness and notes on zoogeography // J. Limnol.Vol.72 (s2). P.109-124.

Korovchinsky N.M. 2018. Cladocera: Ctenopoda. Families Sididae, Holopediidae \& Pseudopenilidae (Branchiopoda: Cladocera). Identification Guides to the Plankton and Benthos of Inland Waters, 27. Weikerscheim (Germany): Backhuys Publ. \& Margraf Publ. 203 p.

Korovchinsky N.M., Sanoamuang L.-o. 2008. Overview of Sididae (Crustacea: Cladocera: Ctenopoda) of Northeast and East Thailand, with description of a new species of the genus Diaphanosoma // Zootaxa. Vol.1682. P.45-61.

Korovchinsky N.M., Sanoamuang L.-o. 2013. Comparative investigation of Sididae (Crustacea: Branchiopoda: Cladocera) of Northern and Western Thailand, with additional notes on Diaphanosoma senegal isanensis Korovchinsky et Sanoamuang, 2008 // Arthropoda Selecta. Vol.22. No.3. P.217-226.

Kotov A.A., Van Damme K., Bekker E.I., Siboualipha S., Silva-Briano M., Ortiz A.A., De la Rosa R.G., Sanoamuang L.-o. 2013. Cladocera (Crustacea: Branchiopoda) of Vientiane province and municipality, Laos // J. Limnol. Vol.72 (s2). P.81-108.

Martin J.W., Cash-Clark C.E. 1995. The external morphology of the onychopod 'cladoceran' genus $B y$ thotrephes (Crustacea, Branchiopoda, Onychopoda, Cercopagididae), with notes on the morphology and phylogeny of the order Onychopoda // Zool. Scr. Vol.24. P.61-90.

Richter S., Olesen J., Wheeler W.C. 2007. Phylogeny of Branchiopoda (Crustacea) based on a combined analysis of morphological data and six molecular loci // Cladistics. Vol.23. P.1-36.

Shirota A. 1966. The plankton of South Viet-Nam. Freshwater and marine plankton. Japan: Overseas Techn. Coop. Agency. 489 p.

Tanaka S., Ohtaka A. 2010. Freshwater Cladocera (Crustacea, Branchiopoda) in Lake Tonle Sap and its adjacent waters in Cambodia // Limnology. Vol.11. P.171178 .

Responsible editor A.Yu. Sinev 